\title{
Transforaminal epidural steroid injection and infraneural approach
}

\author{
Transforaminal epidural steroid enjeksiyonu ve infranöral yaklaşım
}

\author{
(1) Tülin ARICI, (1) Mustafa KURÇALOĞLU, (1) Can EYIGÖR, @ Meltem UYAR
}

\begin{abstract}
Summary
Transforaminal epidural steroid injections are a common intervention in the treatment of radicular pain. Complications are rare, but can be catastrophic. One of the potentially devastating complications is occlusion of the artery of Adamkiewicz (AKA). This report is a description of an approach to avoid the complication of injury to the AKA related to transforaminal epidural injection. A 71-year-old male patient presented at the clinic with radiculopathy secondary to lumbar disc hernia. A transforaminal epidural steroid injection was planned. After a radiocontrast injection, vascular filling was detected. The needle was repositioned and an inferior entrance to the epidural space was used. No vascularity was seen and dexamethasone was administered to the patient. A transforaminal epidural steroid injection is an effective interventional treatment for radicular pain, but it requires careful attention due to the possible complications. The AKA was located in the upper half of the foramen. Keeping the wide variation in the anatomy of the AKA in mind is very important in order to prevent spinal cord ischemia.
\end{abstract}

Keywords: Artery of Adamkiewicz; infraneural approach; spinal cord ischemia; transforaminal epidural injection.

\section{Özet}

Transforaminal epidural steroid enjeksiyonu radiküler ağrı tedavisi için kullanılan yaygın bir girişimdir. Komplikasyonları nadir fakat katastrofiktir. En nadir katastrofik komplikasyonlarından biri Adamkiewicz arter (AKA) oklüzyonu ile ilgilidir. Bu sunumda transforaminal epidural steroid enjeksiyonu ile ilişkili AKA injurisinden kaçınmak için uyguladığımız yaklaşımı sunduk. 71 yaşında erkek hasta kliniğimize lomber disk hernisine bağlı radikülopati ile başvurdu. Hastaya transforaminal steroid enjeksiyonu planlandı. Radyokontrast enjeksiyonu sonrasında vasküler dolum görüldü. Bunun üzerine iğneye yeniden pozisyon verilerek epidural alana ulaşmak için inferior giriş uygulandı. Vasküler yayılım görülmedi ve dexametazon enjekte edildi. Transforaminal epidural enjeksiyon radiküler ağrı için efektif bir girişimsel ağıı tedavisidir. Fakat muhtemel katastrofik komplikasyonlar nedeniyle dikkatli olmayı gerektirir. AKA büyük oranda foramenin üst yarısında lokalizedir. Spinal kord iskemisini önlemek için AKA'nın çok geniş bir anatomik varyasyona sahip olduğunu akılda bulundurmak çok önemlidir.

Anahtar sözcükler: Adamkiewicz arteri; infranöral yaklaşım, spinal kord iskemisi; transforaminal epidural enjeksiyon.

\section{Introduction}

Transforaminal epidural steroid injections are common interventions in the treatment of radicular pain. The procedure involves flouroscopy imaging and radiocontrast liquid usage to evaluate epidural distribution, correcting the needle position and a possible intrathecal or intra vascular relation. ${ }^{[1]}$ Complications are rare but catastrophic. Serious complications of epidural injection are epidural hematoma, abscess, cerebrospinal fluid fistula, hypersensitivity reaction, arachnoiditis and menengitidis. ${ }^{[2,3]}$

One of the rarest catastrophic complications has been related to artery of Adamkiewicz (AKA) oclu- sion. The pathophysiology of spinal cord ischemia associated with epidural steroid injections is believed to be due to direct vascular trauma of AKA, arterial vasospasm or emboli related to the treatment of particulate steroid. ${ }^{[1,2,4]}$ The risk is higher at the upper lumbar levels. ${ }^{[2]}$ There are case reports that present paraplegia related to spinal cord infarction during thoracal or lumbar transforaminal epidural steroid injection even if it has been performed via traditional imaging techniques..$^{[1-4]}$

In this report we present our approach to avoid the complication in which injury of AKA is related to transforaminal epidural injection.

\section{Department of Anesthesiology and Reanimation, Pain Clinic, Ege University, Izmir, Turkey}

Submitted (Başvuru tarihi) 06.03.2017 Accepted after revision (Düzeltme sonrası kabul tarihi) 25.07.2017 Available online date (Online yayımlanma tarihi) 08.04.2019

Correspondence: Dr. Tülin ARICI. Batıkent Mh., 52 nolu Sok., No: 2, Daire: 5, 27050 Gaziantep, Turkey.

Phone: +90 - 530 - 8267310 e-mail: arici-tulin@hotmail.com

(c) 2019 Turkish Society of Algology 


\section{Case Report}

A 71-year old male patient applied to our clinic with radiculopathy secondary to lumbar disc hernia. Because patient's MRI demonstrated left lumbar disc hernia at the level of L4-L5, transforaminal epidural steroid injection was planned to the patient. The patient was placed in the prone position on a fluoroscopy-compatible operating table. After aseptic preperation and draping, $22 \mathrm{G}$ spinal needle was inserted transforaminally to the epidural space from the left side at the level of L4-L5 with fluoroscopic guidance. Correct placement of the needle was confirmed by antero-posteior and lateral radiographs. Radiocontrast liquid was injected to correct the needle position, eliminating intrathecal or intravascular spreading. After radiocontrast injection, vascular filling was detected (Fig. 1). It was seen that vascular structure had reached the anterior part of the vertebral corpus. We concluded that this anatomical structure might be a radicular artery (maybe AKA) that perfused spinal cord and lengthened as a lumbar artery.

Afterwards, the neddle was repositioned and was performed inferior entrance to the epidural space. No vascularity was seen and dexamethasone was injected to the patient. There weren't any complications during the procedure or at follow-up.

\section{Discussion}

Transforaminal epidural injections should be approached with caution as to the potential presence of anatomical variants that may allow injection of corti-

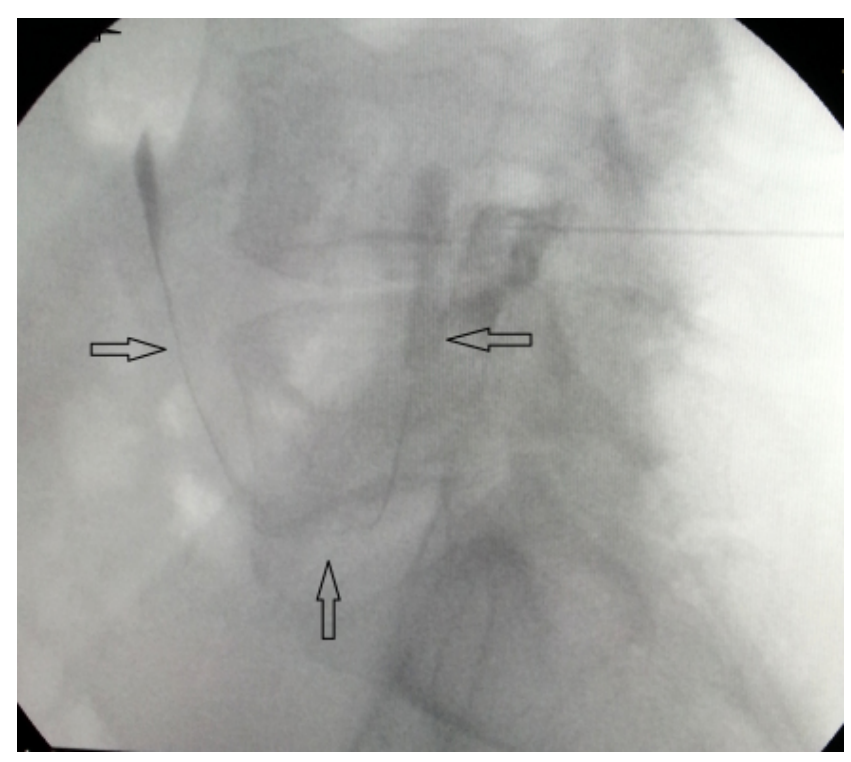

Figure 1. Vascular spread follow-up contrast injection. costeroids into segmental medullary feeding vessels joining the anterior spinal arterial circulation. ${ }^{[5]}$

Segmental vessels of the spinal cord orginates from subclavian artery at cervical region and from aorta via intercostal and lumbar arteries at thoracolombar region. It continues as radiculo-medullary artery and divides into an anterior and a posterior radicular artery. The radicular arteries penetrate dura mater and reach the medulla only at certain levels. Only a few of these segmental branches are present in adults (2-14, avarage 6). The anterior radicular artery divides into a descending and an ascending branch. Anterior spinal artery is an anastomotic channel between ascending and descending branches of neighbouring anterior radicular arteries. One anterior radicular artery is always dominant in terms of size, therefore it is called arteria radicularis magna or great radicular artery or artery of Adamkiewicz. Posterior radicular artery shows a similar pattern and divides into 2 longitudinal anastomotic channels (posterolateral spinal arteries). In conclusion 3 longitudinal artery trunks provides the vascular construction of the spinal cord: 1 anterior spinal artery and 2 posterior spinal arteries. $[2,6,7]$

AKA is the most important feeding artery of the thoracolumbar spinal cord. ${ }^{[1]}$ AKA perfuses anterior part of the $2 / 3$ lower spinal cord. The trauma of this artery may lead to cord ischemia; it manifests as anterior spinal artery syndrome with impaired motor and sensory function of the bilateral lower extremities and loss of urinary and fecal continence. ${ }^{[6]}$

AKA is often located on the left side and at T8-L1 levels, but it could be situated in a place between $\mathrm{T} 2$ and S1. The highest incidence was at T9-12.Although it is rare, a person may have two AKAs. ${ }^{[1,8,9]}$ Murthy at al. ${ }^{[1]}$ showed that AKA is located on the left side $83 \%$ and on the right side $17 \%$ in a study. The AKA was located in the upper one half of the foramen $97 \%$, in the upper third of the foramen $88 \%$, in the middle third of the foramen $9 \%$, in the lower third of the foramen $2 \%$. The AKA was never seen in the most inferior one fifth of the foramen. It was always at between T2-L3 levels, with $92 \%$ located between T8-L1 and the highest incidence was at T10 (28\%). In an angiographic series, Lo at al. ${ }^{[10]}$ revealed AKA at L4 level in 3 cases.

In our case, the injection was performed from left 
side and at L4-L5 interforaminal space. According to previous studies, AKA may be present at this level. We may increase vascular spread ratio with safe triange approach when we try to prevent nerve damages according to previous literature. Murthy at al. ${ }^{[1]}$ emphasized this and they suggest inferior or slightly posterior approach rather than the area called 'safe triangle' (just caudal [6 O'clock] of superior pedicle at upper part of the foramen) because AKA is located at higher rates at superior of $L 3$ level and it enters to spinal channel by superior part of the neural foramen in high quantiaties.

In our case we performed a safe triangle approach and saw the vascular spread. This may be a possible radicular artery or even AKA, so we performed infraneural approach and eliminated vascular spread. Also we perfomed a safe intervention via administering the less particulated steroid, dexamethasone as suggested in the guidelines, it is a controversial subject. ${ }^{[1,3,4]}$ Houton and Errico ${ }^{[3]}$ has reported 3 paraplagia cases related to particulated steroid administration and Kader at al. ${ }^{[2]}$ have reported a paraplagia case after particulated steroid administration. Negative blood aspiration does not exclude vascular penetration. Therefore attentive radiocontrast injection to exclude vascular filling is important and mandatory. ${ }^{[11]}$ Digital subtraction imaging is an extremely sensitive way to detect vascular opacification..$^{[5,11]}$

Transforaminal epidural steroid injection is an effective interventional treatment for radicular pain but it needs to be careful because of the possible catastrophic complications. Keeping in mind wide variation range of anatomy of AKA is very important in preventing the spinal cord ischemia.

\section{Conflict-of-interest issues regarding the author- ship or article: None declared.}

\section{Peer-rewiew: Externally peer-reviewed.}

\section{References}

1. Murthy NS, Maus TP, Behrns CL. Intraforaminal location of the great anterior radiculomedullary artery (artery of Adamkiewicz): a retrospective review. Pain Med 2010;11(12):1756-64. [CrossRef]

2. AbdeleRahman KT, Rakocevic G. Paraplegia following lumbosacral steroid epidural injections. J Clin Anesth 2014;26(6):497-9. [CrossRef]

3. Houten JK, Errico TJ. Paraplegia after lumbosacral nerve root block: report of three cases. Spine J 2002;2(1):70-5.

4. Abdi S, Datta S, Lucas LF. Role of epidural steroids in the management of chronic spinal pain: a systematic review of effectiveness and complications. Pain Physician 2005;8(1):127-43.

5. Huntoon MA. Cervical Spine: Case Presentation, Complications, and Their Prevention. Pain Medicine 2008;S35-40.

6. Bredow J, Oppermann J, Keller K, Beyer F, Boese CK, Zarghooni $\mathrm{K}$, et al. Anterior spinal artery syndrome: reversible paraplegia after minimally invasive spine surgery. Case Rep Orthop 2014;2014:205732. [CrossRef]

7. Melissano G, Chiesa R. Advances in imaging of the spinal cord vascular supply and its relationship with paraplegia after aortic interventions. A review. Eur J Vasc Endovasc Surg 2009;38(5):567-77. [CrossRef]

8. Tatsuya Nishii, Atsushi K. Kono, Noriyuki Negi,H Hashimura, K Uotani, Y Okita, K Sugimura. The Feasibility of a 64-slice MDCT for detection of the Adamkiewicz artery: comparison of the detection rate of intravenous injection CT angiography using a 64-slice MDCT versus intra-arterial and intravenous injection CT angiography using a 16-slice MDCT. Int J Cardiovasc Imaging (2013) 29:127-133. [CrossRef]

9. Melissano G, Bertoglio L, Civelli V, Amato AC, Coppi G, Civilini $\mathrm{E}$, et al. Demonstration of the Adamkiewicz artery by multidetector computed tomography angiography analysed with the open-source software OsiriX. Eur J Vasc Endovasc Surg 2009;37(4):395-400. [CrossRef]

11. Lo D. Vallee JN, Spelle K, Cormier E, Saillant G, Rancurel G, et al. Unusual origin of the artery of Adamkiewicz from the fourth lumbar artery. Neuroradiology 2002;44(2):153-7.

12. Furman MB, O'Brien EM, Zgleszewski TM. Incidence of intravascular penetration in transforaminal lumbosacral epidural steroid injections. Spine (Phila Pa 1976) 2000;25(20):2628-32. [CrossRef] 